\title{
Biogeochemical significance of bacterial biomass in the ocean's euphotic zone
}

\author{
Byung C. Cho, Farooq Azam \\ Scripps Institution of Oceanography, University of California, San Diego, La Jolla, California 92093, USA
}

\begin{abstract}
Bacterial abundance and biomass were extensively measured in the euphotic zone at several oligotrophic and mesotrophic sites of coastal and open Pacific ocean during different seasons. Comparisons with phytoplankton biomass and with particulate organic carbon (POC) were made in order to determine the quantitative significance of bacteria as a carbon and nitrogen pool in the euphotic zone. Analysis of our data and that from the literature showed that bacterial abundance in the euphotic zone has a lower threshold of ca $3 \times 10^{5} \mathrm{ml}^{-1}$ or $6 \mu \mathrm{g} \mathrm{Cl} l^{-1}$ Consequently, with increasingly oligotrophic conditions photoautotrophic biomass may decrease well below the bacterial biomass. In oligotrophic waters bacterial biomass was commonly 2 to 3 times greater than phytoplankton biomass. In contrast, in mesotrophic to eutrophic waters bacterial biomass was generally much less than phytoplankton biomass. Comparison with total POC (which included bacterial carbon) showed that in oligotrophic waters bacterial biomass averaged $40 \%$ (range 26 to $62 \%$ ) of POC. Inexplicably, the sum of bacterial carbon and phytoplankton carbon was always about one-half of POC. The dominance of bacterial biomass over phytoplankton biomass in oligotrophic oceans has significant implications for the food-web structure, nutrient cycling pathways, and for sinking flux of organic matter Future studies should examine the physiological and trophic mechanisms which lead to the dominance of bacterial biomass in oligotrophic systems but of photoautotrophic biomass in the eutrophic systems.
\end{abstract}

\section{INTRODUCTION}

The oceans' ability to vertically transport and sequester surface-derived materials depends on a complex of biological and physiochemical processes which mediate material fluxes amongst dissolved, suspended-particulate, and sinking-particulate phases in the ocean (Fowler \& Knauer 1986). Food-web structure and organism size-spectrum are important determinants of what fraction of photosynthetically fixed carbon sinks out of the upper mixed layer (Eppley \& Peterson 1979). Whether bacteria or phytoplankton and detritus dominante the food for grazers in the euphotic zone is likely to influence the food-web structure, nutrient cycling, and sinking flux. It is therefore of interest to determine the magnitude of bacterial biomass as a particulate carbon and nitrogen pool relative to other major particulate pools of these elements which participate in nutrient cycling and sinking flux.

Linley et al. (1983) and Bird \& Kalff (1984) found a significant positive relationship between bacterial abundance and chlorophyll a (chl a). From analysis of a large data set from the literature, Bird \& Kalff (1984) showed that as one goes from eutrophic to mesotrophic waters bacterial abundance decreases less slowly than chl a. Extrapolation from their equation suggests that bacterial biomass relative to phytoplankton biomass would be more significant in oligotrophic waters than in eutrophic waters. However, the analysis in Bird \& Kalff (1984) did not cover oligotrophic waters (only one data point had $<0.1 \mu \mathrm{g} \mathrm{chl} a^{-1}$ ). Dortch \& Packard (1989) reported that the particulate protein/chl a ratio (an index of the relative biomasses of heterotrophic and photoautotrophic organisms) increased sharply as the $\mathrm{chl}$ a level in the water decreased to those typical of the oligotrophic oceans. They proposed that the food webs in eutrophic waters are dominated by primary producer biomass while food webs in oligotrophic waters are dominated by decomposer biomass. Whether heterotrophic animals or bacteria were responsible for the dominance of heterotrophic biomass in oligotrophic waters could result in profoundly different biogeochemical states of the oligotrophic oceans. This distinction was not attempted in the study of Dortch \& Packard (1989).

We have studied the magnitude of bacterial biomass 
in relation to phytoplankton biomass and particulate organic carbon (POC) in oligotrophic and mesotrophic waters. Our results suggest the hypothesis that bacterial biomass can be a major factor in food-web structure, nutrient cycling pathways, and biogeochemical dynamics particularly in oligotrophic oceans.

\section{MATERIALS AND METHODS}

Sampling. In the central North Pacific gyre ('gyre'; at about $28^{\circ} \mathrm{N}, 115^{\circ} \mathrm{W}_{\text {; }}$ Laws et al. 1987) samples were taken between 19 August and 5 September 1985 from the RV 'Melville' during the PRPOOS (Plankton Rate Processes in the Oligotrophic Ocean) cruise. Water was collected with $30 \mathrm{l}$ Go-Flo (General Oceanics) bottles or with a CTD (conductivity-temperature-depth) rosette system equipped with $10 \mathrm{l} \mathrm{Niskin} \mathrm{bottles.} \mathrm{Two} \mathrm{areas} \mathrm{in}$ Southern California coastal waters were studied; the Southern California Bight ('bight'; at about $118^{\circ} 30^{\prime}$ to $117^{\circ} 15^{\prime} \mathrm{W}, 32^{\circ} 30^{\prime}$ to $33^{\circ} 30^{\prime} \mathrm{N}_{\text {; Eppley }} 1986$ ) and Santa Monica basin ('basin'; at about $119^{\circ} 10^{\prime}$ to $118^{\circ} 30^{\prime} \mathrm{W}$, $33^{\circ} 20^{\prime}$ to $34^{\circ} \mathrm{N}$; Eppley 1986). Seawater was collected with Niskin bottles during the RV 'Sproul' cruise (1 to 4 May 1985) in the bight, and in the basin during the RV 'New Horizon' cruise 16 to 20 May 1986; 20 to 25 Oct $1986 ; 8$ to 12 Oct 1987). All sampling bottles were acidcleaned and rinsed with distilled water before use. Detailed biological and hydrographic data for our study areas during the PRPOOS cruise can be found in Eppley et al. (1988), and for the bight and basin in Eppley (1986).

Measurements and data analysis. Bacteria were counted by epifluorescence microscopy using the acridine orange direct count (AODC) method (Hobbie et al. 1977) except for PRPOOS cruise samples which were stained with 4', 6-diamidino-2-phenylindole (DAPI; Porter \& Feig 1980). Biovolume measurements for bacteria followed the method of Ammerman et al. (1984), except that we used fluorescent beads to calibrate biovolume measurements. To decide the extent of the halo in epifluorescence images we employed the criteria of Lee \& Fuhrman (1987). Bacterial biovolume was converted to bacterial carbon (BOC) on the basis that bacteria smaller than $0.073 \mu^{3}{ }^{3}$ contain $20 \mathrm{fg} C$ per cell (Lee \& Fuhrman 1987; also see 'Discussion'). All our samples had mean bacterial volumes in the range 0.03 to $0.06 \mu^{3}$. Between 60 and 300 cells were measured for volume determination. POC was measured by the CHN analysis method of Sharp (1974); seawater was filtered through baked $\left(500^{\circ} \mathrm{C}\right) \mathrm{GF} / \mathrm{F}$ filters, and the filters were kept frozen $\left(20^{\circ} \mathrm{C}\right)$ until analyzed in the shore laboratory. Chl a was measured by the fluorometric method of Strickland \& Parsons (1972).

Phytoplankton carbon in some of the gyre samples (identified in 'Results') was calculated on the basis of chl a measurements and the C/chl a ratio of $47 \pm 24$ determined for other samples but for the same site and cruise (Redalje pers. comm.) by the labeled chl a method of Redalje \& Laws (1981). In the bight and the basin, phytoplankton carbon (Cp) was calculated on 2 bases for each sample, as chl a $\times 50$ (Eppley et al. 1977 , Redalje 1983) and as POC $\times 0.158+$ POC $^{2} \times 0.0007$ (Eppley et al. 1977). There is considerable uncertainty in Cp estimates by these 2 methods (see 'Discussion'). However, Redalje (1983) has compared the labeled chl a method with $\mathrm{Cp}$ estimates on the basis of chl a or POC. He concluded that Eppley's POC/Cp relationship gave results quite comparable to those by the labeled chl a method. His results also indicated that $\mathrm{Cp}$ calculated on the basis of chl a $(\mathrm{Cp}=\mathrm{chl} a \times 50)$ was generally within a factor of 2 of estimates by the labeled chl a method

Regression analyses were performed using the computer programs 'LINREG' and 'NLCURV' developed, by B. Stewart at Scripps, for untransformed and transformed data (where indicated).

\section{RESULTS}

\section{Relationship between bacterial abundance and chl a}

Fig. 1 shows that our data for samples in chl a range $>0.5 \mu \mathrm{g} \mathrm{l}^{-1}$ follow reasonably well the pattern observed by Bird \& Kalff (1984). The slope of the regression line

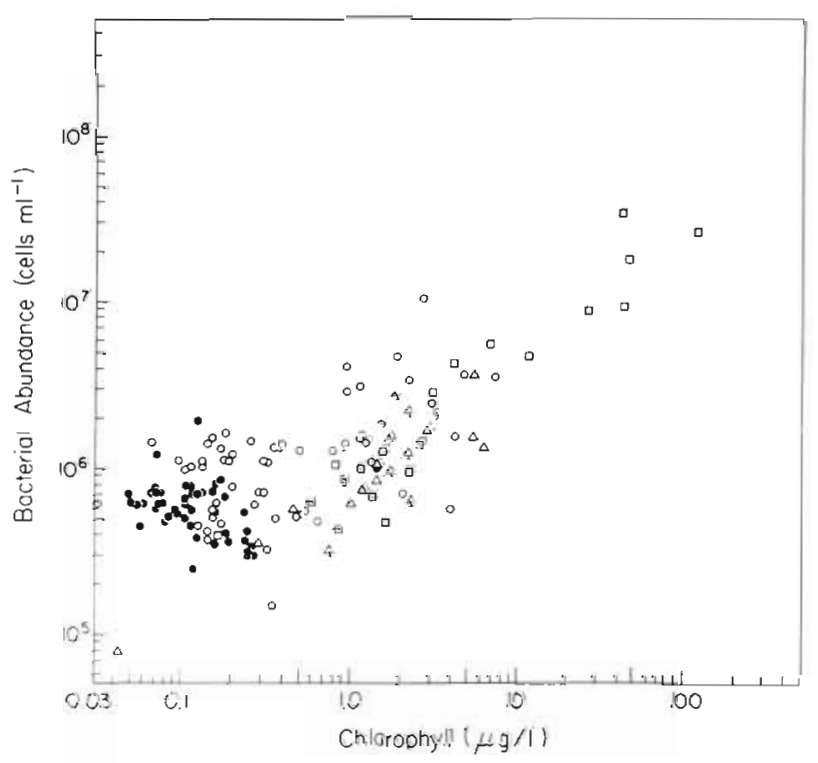

Fig. 1. Relationship between chlorophyll a and bacterial abundance in the euphotic zone. Data are from central North Pacific gyre (•), Southern California Bight and Santa Monica Basin (0), and the data set of Bird \& Kalff (1984) representing various seawater ( 6 ) and freshwater ( $\square$ ) locations 
(not shown) was similar to that for marine samples in the Bird-Kalff plot. The data points for chl a below 0.5 $\mu \mathrm{g} 1^{-1}$ deviate completely however from the Bird-Kalff plot. The slope for data points between 0.03 and $0.5 \mu \mathrm{g}$ chl a $\mathrm{l}^{-1}$ is not significantly different from zero. For chl $a, 98 \%$ of the data points in the range 0.03 to $1.0 \mu^{-1}$ fall within a relatively narrow range of bacterial abundance values $\left(0.3\right.$ to $\left.1.5 \times 10^{6} \mathrm{ml}^{-1}\right)$. Thus, a 33 -fold decrease in the chl a level was accompanied by only a 5 -fold variation in bacterial abundance.

\section{Relationship between bacterial carbon and phytoplankton carbon}

As would be expected from the relationship between chl $a$ and bacterial abundance shown in Fig. 1, the derived parameter $\mathrm{BOC} / \mathrm{Cp}$ increases dramatically in samples containing $<0.2 \mu \mathrm{g} \mathrm{chl} \mathrm{a}^{-1}$ (Fig. 2). In this

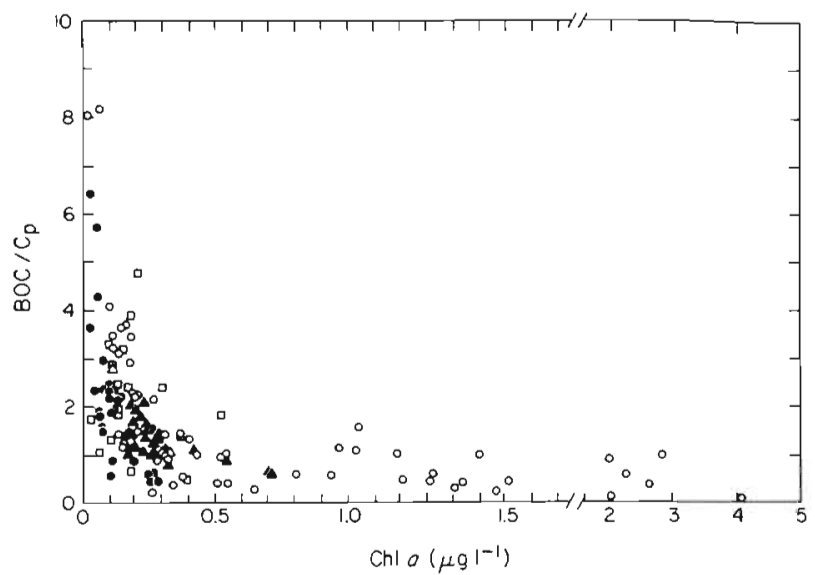

Fig. 2. Plot of bacterial carbon/phytoplankton carbon (BOC/ Cp) vs chlorophyll a for euphotic zone samples from: central North Pacific gyre (•), Southern California Bight ( $\square$ : Cp was calculated as POC $\times 0.158+\mathrm{POC}^{2} \times 0.0007, \mathrm{O}: \mathrm{Cp}$ was calculated as chl $a \times 50$; see text for details), and along a transact from San Pedro to San Diego ( 4 ; Cp calculated as chl $a \times 50$ )

range of chl a all but 3 values of $\mathrm{BOC} / \mathrm{Cp}$ were $>1$, $82 \%$ were between 1 and 4 , and in 2 cases $\mathrm{BOC} / \mathrm{Cp}$ exceeded 8 . The results in Fig. 2 also show that $\mathrm{BOC}$ exceeded $\mathrm{Cp}$ in $95 \%$ of cases in waters with $<0.2 \mu \mathrm{g}^{-1}$ chl a. The Cp values plotted in Fig. 2 were calculated in the majority of samples on the basis of chl a but in 17 samples Cp was calculated on the basis of the relationship between Cp and POC (Eppley et al. 1977). It should be noted that both techniques yielded similar results. Using POC-based Cp, BOC in 11 out of 12 samples containing $<0.2 \mu \mathrm{g}$ chl a $1^{-1}$ exceeded $\mathrm{Cp}$ as was the case in samples where $\mathrm{Cp}$ was calculated as $\mathrm{chl} a \times 50$. It should also be noted that high $\mathrm{BOC} / \mathrm{Cp}$ in
Fig. 2 was not restricted to oligotrophic samples; about one-third of $>0.5 \mu \mathrm{g} \mathrm{chl} \mathrm{a} \mathrm{l}^{-1}$ samples also had BOC/Cp -1 (but not much higher).

\section{Relationship between bacterial carbon and POC}

A plot of $1 / \mathrm{BOC}$ versus $1 / \mathrm{POC}$ of all data for the basin and the gyre (Fig. 3a) shows a highly significant relationship: $1 / \mathrm{BOC}=0.0205+2.0946 / \mathrm{POC}\left(\mathrm{r}^{2}=0.43\right.$; $\mathrm{p}<0.01$ ). The relationship between BOC and POC (Fig. 3b) is best described by a curvilinear, saturationtype plot. A plot of BOC/POC versus POC (Fig. 3c) showed that the data could be divided into 2 sets: In the $\mathrm{POC}$ range $<59 \mu \mathrm{g} \mathrm{C} \mathrm{l}^{-1}$, most $\mathrm{BOC} / \mathrm{POC}$ values clustered between 0.27 and 0.62 (i.e. when $\mathrm{POC}$ was $<59$ $\mu \mathrm{gl}^{-1}, 27$ to $62 \%$ of it was due to $\mathrm{BOC}$, with an average of $40 \pm 16$ ). At POC values $>59 \mu \mathrm{g} \mathrm{C} \mathrm{l}^{-1}$, however, there was a regular decline of $\mathrm{BOC} / \mathrm{POC}$ with increasing $\mathrm{POC}$, and $\mathrm{BOC} / \mathrm{POC}$ values decreased to 0.14 at POC concentration of $190 \mu \mathrm{g} \mathrm{l}^{-1}$. If we consider the entire range of $\mathrm{POC}$ values in Fig. $3 \mathrm{C}$, then $\mathrm{BOC} / \mathrm{POC}$ does not covary with $\mathrm{POC}$ due to the clustering of data points in the low POC range. However, in the entire data set in Fig. 3c covering a broad range of POC value BOC was never less than $14 \%$ of POC. Fig. 3 d shows that the sum of BOC and Cp was roughly $50 \%$ of POC at all POC values from 20 to $200 \mathrm{\mu g} \mathrm{l}^{-1}$.
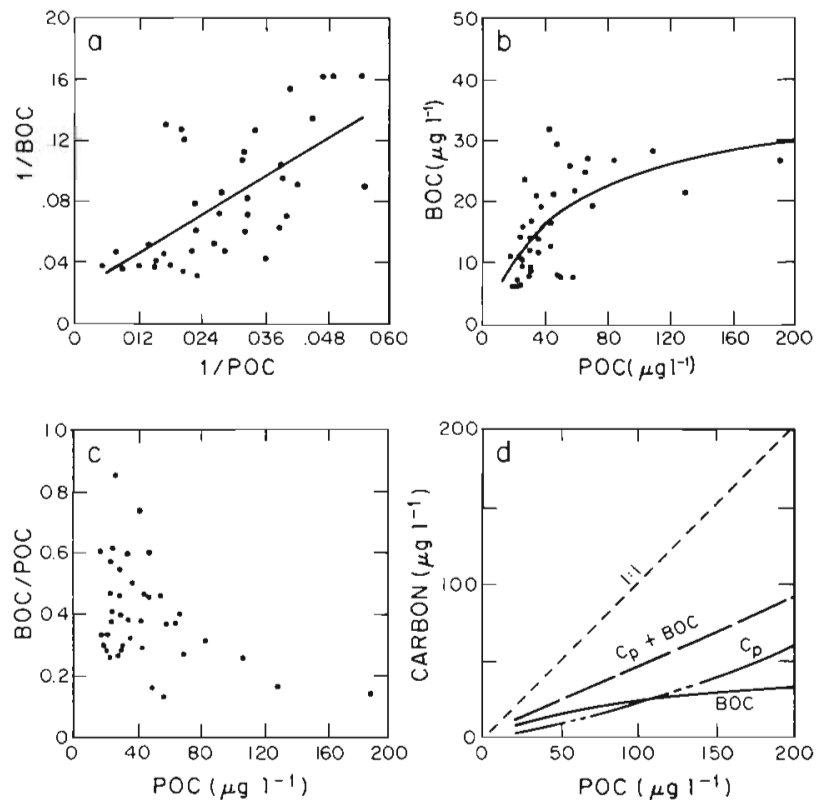

Fig. 3. (a) Reciprocal plot of bacterial carbon (BOC) versus POC for all the data from the euphotic zones of all study areas (see text for locations). Data of BOC and POC were transformed to obtain linear regression: $1 / \mathrm{BOC}=0.0205+2.0946 /$ POC, $r^{2}=0.43, p<0.05$. (b) Non-linear relationship between $\mathrm{BOC}$ and $\mathrm{POC}$ using the same data as in (a). (c) Plot of BOC/ $P O C$ vs POC for the same data as in (a). (d) Relationships of $\mathrm{POC}$ with $\mathrm{BOC},(\mathrm{BOC}+\mathrm{Cp})$, and $\mathrm{Cp}$ 


\section{DISCUSSION}

A striking result from this study is that in the euphotic zones of oligotrophic waters bacterial carbon was usually equal to or greater than phytoplankton carbon (Fig. 2). An empirical explanation (Fig. 1) is that bacterial abundance in the euphotic zone has a lower threshold of ca $3 \times 10^{5} \mathrm{ml}^{-1}\left(6 \mu \mathrm{g} \mathrm{Cl} \mathrm{l}^{-1}\right)$ at our study stations (and possibly in general). Only 3 of 142 samples (102 of ours and 40 from Bird \& Kalff 1984) in the data set covering from highly oligotrophic to mesotrophic waters during various seasons had bacterial abundances less than $3 \times 10^{5} \mathrm{ml}^{-1}$. We do not know what mechanisms are responsible for maintaining bacterial abundance at these fairly high levels even in highly oligotrophic waters where nutrient supply greatly limits the photoautotrophic biomass. Bacterivore populations in oligotrophic waters may be too low to exert a strong predation pressure, or bacterivores may not feed efficiently below $3 \times 10^{5} \mathrm{ml}^{-1}$ (ca $2 \times 10^{5}$ $\mathrm{ml}^{-1} ; \mathrm{J}$. Wikner pers. comm.). Whatever the mechanism, an important consequence of the phenomenon is that in oligotrophic waters bacteria biomass is dominant over phytoplankton biomass, and most $\mathrm{C}$ and $\mathrm{N}$ occurs sequestered in bacteria. The opposite is true for eutrophic waters

Despite a 2 orders-of-magnitude variation in $\mathrm{BOC} /$ $\mathrm{Cp}$ (Fig. 2) the ratio of bacterial production to primary production did not show parallel variation (not shown). About one-half of the primary production was channeled via bacteria in the gyre (Cho \& Azam 1988) and in the bight and the basin (Fuhrman et al. 1980, Fuhrman \& Azam 1982, Cho \& Azam 1988). These results are consistent with the generalization of Cole et al. (1988) that irrespective of the trophic status of the environment bacterial production requires ca $40 \%$ of primary production to support it. It follows that the bacteria assemblage growth rate will decline as BOC/ $\mathrm{Cp}$ increases. Bacteria in the gyre samples grew very slowly (generation time ca $10 \mathrm{~d}_{i}$ Cho \& Azam 1988) compared with the phytoplankton $\left(\mu \sim 1 \mathrm{~d}^{-1}\right.$; Laws et al. 1987). Indeed, a much lower growth (and turnover) rate of bacteria compared with phytoplankton is a necessary condition for maintaining a high $\mathrm{BOC} / \mathrm{Cp}$ because heterotrophic bacteria depend on phytoplankton for reduced carbon.

Dortch \& Packard (1989) pointed out that the food webs in oligotrophic and eutrophic waters must be fundamentally different. Their conclusion is based on the observation that protein/chl a ratio (a rough measure of the dominance of the heterotrophic biomass over the photoautotrophic biomass) is very high in oligotrophic waters and gradually decreases to low values as chl a values increase to those in eutrophic waters. They introduced the notion that the food webs in the oligotrophic waters can be represented by an inverted pyramid with the heterotrophic biomass dominating the photoautotrophic biomass. Our results on the variation of $\mathrm{BOC} / \mathrm{Cp}$ are consistent with the idea of Dortch \& Packard (1989) and further extend their notion by showing that the dominance of heterotrophic biomass observed by them in oligotrophic waters could be explained by the persistence of high bacterial biomass. Thus, the high $\mathrm{BOC/Cp}$ may reflect (or cause) fundamentally different organization of foodwebs in the oligotrophic and eutrophic waters.

Might our conclusions be artefacts of methods for measuring various carbon pools? Measurement of $\mathrm{Cp}$ is problematic, and several approaches have been proposed and evaluated (for analyses of this issue, see Eppley et al. 1977, Redalje 1983). Eppley et al. (1977) compared 7 different methods in Southern California coastal waters, including the area studied here by us. They concluded that the most reliable approach was to calculate $\mathrm{Cp}$ on the basis of POC ( $\mathrm{Cp}=0.158 \times \mathrm{POC}+$ $0.0007 \mathrm{POC}^{2}$ ). More recently, the chl a labeling method of Redalje \& Laws (1981) has provided an elegant way to directly measure $\mathrm{Cp}$ in natural samples. Redalje (1983) compared the chl a labeling method with 4 other methods and concluded that the POC-based method (Eppley et al. 1977) agreed best with Redalje-Laws method; the agreement was particularly good for oligotrophic to mesotrophic waters in the bight. In Fig. 1, use of both these methods led to identical conclusions regarding the high magnitude of $\mathrm{BOC} / \mathrm{Cp}$ in oligotrophic samples. In Fig. 2, we have also included 2 data sets in the bight where $\mathrm{Cp}$ was roughly estimated as chl a $\times 50$. These values were included because they cover the higher chl a range that our other data do not. The choice of 50 as a multiplier is an approximation based on the empirical observations of Redalje (1983); using the Redalje-Laws method the $\mathrm{C} / \mathrm{Chl}$ a ratio was found to be 20 to 70 for their stations in the bight. Since all 3 methods yielded a similar relationship between $\mathrm{Cp}$ and $\mathrm{BOC} / \mathrm{Cp}$ we think it is quite improbable that the general pattern in Fig. 2 is an artefact of the methods for measuring $\mathrm{Cp}$. A second independent line of evidence supports our general conclusion that oligotrophic waters have high $\mathrm{BOC} / \mathrm{Cp}$. In our oligotrophic samples BOC/POC in a number of samples was ca 0.5 (Fig. 3c), meaning that BOC was equal to all nonbacterial $P O C$ including $C p$, animals, and detritus. It follows then that in our oligotrophic samples $B O C$ would have been greater than $\mathrm{Cp}$.

Bacterial $\mathrm{C}$ /volume ratio has recently been the subject of intensive study and discussion. Measurements by several groups have shown that pelagic bacteria have a very high carbon content $[350 \mathrm{mg} \mathrm{C} \mathrm{m}]^{-1}$. Bjørnsen (1986); $380 \mathrm{mg} \mathrm{C} \mathrm{ml}^{-1}$, Lee \& Fuhrman (1987); $560 \mathrm{mg} \mathrm{C} \mathrm{ml}^{-1}$, Bratbak (1985); $400 \mathrm{mg} \mathrm{C} \mathrm{ml}^{-1}$, Simon 
\& Azam (1989)]. Lee \& Fuhrman (1987) found empirically that bacteria in the 0.036 to $0.073 \mu \mathrm{m}^{3}$ range uniformly contained $20 \mathrm{fg} \mathrm{C}$ cell $^{-1}$. Simon \& Azam (1989) computed bacterial cell carbon on the basis of bacterial protein measurements and a macromolecular inventory of small pelagic bacteria. They concluded that 0.036 and $0.07 \mu^{3}$ bacteria would have 13 and 19 fg $\mathrm{C} \mathrm{cell}^{-1}$, respectively. These values are somewhat lower than those of Lee \& Fuhrman (1987) because Simon \& Azam (1989) may not have accounted for all the cellular components in their biochemical inventory. Simon \& Azam (1989) speculate that as bacteria become smaller they lose water out of proportion to their dry weight and carbon, thus gradually becoming 'dry' and carbon rich. We used the empirical factor of Lee \& Fuhrman (1987; $20 \mathrm{fg} \mathrm{C}^{\mathrm{C}}$ cell ${ }^{-1}$ ) because it had been directly determined for natural assemblages of pelagic marine bacteria. We recognize that the smallest bacteria in their analysis would have no space for cell water. Such cells could be spores, but autoradiography and size-fractionation have shown that small bacteria are metabolically active (Fuhrman \& Azam 1982). Volume measurement of small bacteria is subject to significant error, and Lee \& Fuhrman (1987) may have underestimated cell volumes. However, their measurements of carbon per cell, based on CHN analysis and cell counts, are less likely to be in error.

The high BOC/Cp values for the oligotrophic waters have several implications for food-web structure and biogeochemical cycling pathways as well as for the role of bacteria as a pool of fine particulates in seawater. Bacteria and phytoplankton form the pool of biomass from which grazing food chain and microbial loop can start. Thus, the relative dominance of $\mathrm{BOC}$ and $\mathrm{Cp}$ in various waters would be linked to pool sizes which are subject to nutrient cycling and sinking flux of materials. As shown (Fig. 2), in the oligotrophic waters BOC was 1 to 4 times $\mathrm{Cp}$. The $\mathrm{C} / \mathrm{N}$ ratio of natural bacterial assemblages is <4 (Nagata 1986, Lee \& Fuhrman 1987) while that of phytoplankton is 6 to 7 (6.2 in the gyre; Laws et al. 1987). If we assume that these elemental ratios are applicable to the assemblages studied by us then bacterial $\mathrm{N}$ in most of our oligotrophic samples will represent 75 to $86 \%$ of the sum of $N$ in phytoplankton and bacteria. This means that the majority of planktonic $N$ in oligotrophic waters (but a much smaller fraction in the eutrophic waters) occurs sequestered in bacterial cells; it must be mobilized (presumably via the microbial loop; Azam et al. 1983) in order that the growth of both phytoplankton and bacteria may be sustained.

In oligotrophic waters, where the non-sinking bacterial $\mathrm{N}$ dominates the biomass available for vertical export, one would expect low sinking flux of $\mathrm{N}$ and, as a consequence, long turnover time of $\mathrm{PON}$ pool in the

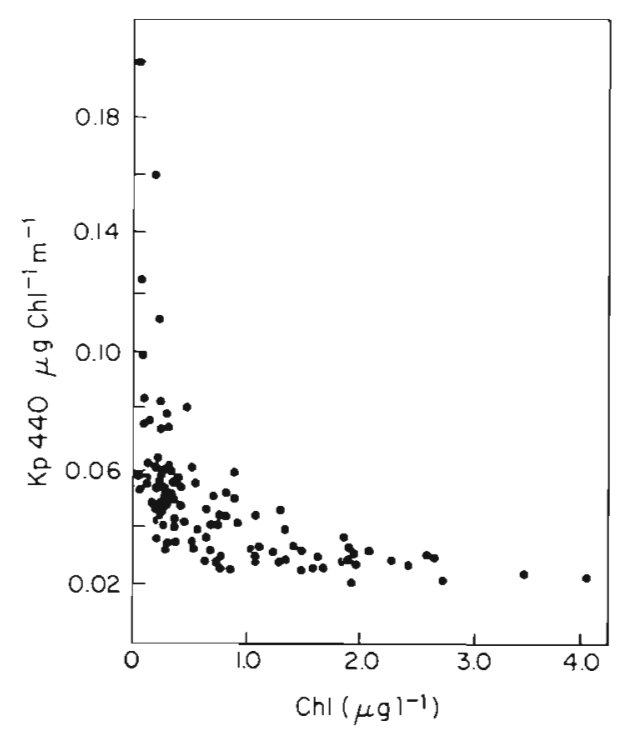

Fig. 4. Plot of chl a versus chl a-specific diffuse attenuation coefficient, Kp. Redrawn from Phinney \& Yentsch (1986)

euphotic zone. In the eutrophic waters, on the other hand, phyto- $\mathrm{N}$ would be dominant and hence the particulate nitrogen will be more exportable there than in the oligotrophic waters. This scenario is consistent with the observed low 'new production' in the oligotrophic and high 'new production' in eutrophic waters (Eppley \& Peterson 1979).

Might the high BOC/Cp in oligotrophic oceans contribute significantly to the upper ocean's biooptical signal and its variability? There is only limited direct evidence bearing on this question. Recently, Spinrad et al. (1989) found in mesocosm studies that changes in bacterial abundance could contribute significantly to the variability in the diffuse attenuation coefficient of seawater. Also, we note a striking similarity (Fig. 4) between our plot of $\mathrm{Cp}$ versus $\mathrm{BOC} / \mathrm{Cp}$ and a plot of chl $a$ vs the chl a-specific diffuse attenuation coefficient, Kp, in Phinney \& Yentsch (1986). The high Kp in oligotrophic waters had been hypothetically attributed to the presence of high levels of fine detritus (Smith \& Baker 1978). We recently reported that in the Pacific Ocean $40 \%$ of POC was bacterial carbon (Cho \& Azam 1988; also Fig. 3c). We believe that this unexplained behavior of $\mathrm{Kp}$ in oligotrophic waters is in part or whole due to bacterial biomass. Kiefer (pers. comm.) found that in oligotrophic surface waters a major fraction of the absorption signal is due to particles $<1 \mu \mathrm{m}$, presumably due to bacterial cytochromes.

The finding that bacterial carbon in oligotrophic waters is a substantial fraction of the total POC and biomass is implicit in several earlier studies which measured bacterial abundance and POC and chl a, but its significance had not previously been discussed (but 
see Cho \& Azam 1987, 1988, Fuhrman et al. 1989). The data of POC and bacterial abundances from Williams et aI. (1980) and Maeda et al. (1983) indicate BOC in oligotrophic waters generally comprises a substantial fraction of $\mathrm{POC}$. We also note an intriguing relationship (Fig. 3d) that the sum of $B O C$ and $\mathrm{Cp}$ is about one-half of POC in all samples from oligotrophic and mesotrophic waters. We cannot explain why this relationship should exist, nor ascertain whether it is a common phenomenon. If this relationship turns out to be a general feature then it could have the practical utility that POC measured in oligotrophic to mesotrophic waters could be used to estimate or hind-cast the sum of $\mathrm{BOC}$ and $\mathrm{Cp}$.

In conclusion, this study has shown that bacteria dominate particulate carbon and nitrogen pools in comparison with phytoplankton and detritus in oligotrophic waters. Future studies should examine the physiological and trophic bases for the dominance of bacterial biomass and incorporate them into models of the ocean's ecological and biogeochemical dynamics.

Acknowledgements. We thank Drs R. E. Eppley, D. G. Redalje, and J. W. Ammerman for making available their unpublished data on chl $a$ and POC, and David C. Smith for valuable comments on the manuscript. Some of the bacterial counts in the gyre were kindly provided by Dr L. Haas. Part of this work was presented at the Ocean Science/AGU meeting in 1987 and was published as an abstract (Cho \& Azam 1987). This work was supported by grants from DOE and NSF, and by a Korean government scholarship to B. C. C

\section{LITERATURE CITED}

Ammerman, J. W., Fuhrman, J. A., Hagström, §., Azam, F. (1984). Bacterioplankton growth in seawater: I. Growth kinetics and cellular characteristics in seawater cultures. Mar. Ecol. Prog. Ser. 18: 31-39

Azam, F., Fenchel, T., Field, J. G., Gray, J. S., Meyer-Reil, L.-A., Thingstad, F. (1983). The ecological role of watercolumn microbes in the sea. Mar. Ecol. Prog. Ser 10: $257-263$

Bird, D. F., Kalff, F. (1984). Empirical relationships between bacterial abundance and chlorophyll concentration in fresh and marine waters. Can. J. Fish. Aquat. Sci. 41: 1015-1023

Bjornsen, P. K. (1986). Automatic determination of bacterioplankton biomass by image analysis. Appl. environ. Microbiol. 51: 1199-1204

Bratbak, G. (1985). Bacterial biovolume and biomass estimations. Appl environ. Microbiol. 49: 1488-1493

Cho, B. C., Azam, F. (1987). Significance of bacterioplankton biomass in the epipelagic and mesopelagic zones in the Pacific Ocean. Eos 68: 1729

Cho, B. C., Azam, F. (1988). Major role of bacteria in biogeochemical fluxes in the ocean's interior. Nature, Lond. 332: 441-443

Cole, J. J., Findlay, S., Pace, M. S. (1988). Bacterial production in fresh and saltwater ecosystems: a cross-system overview. Mar Ecol. Prog. Ser. 43: 1-10
Dortch, Q., Packard, T. (1989). Differences in biomass structure between oligotrophic and eutrophic marine ecosys terns. Deep-Sea Res. 36: 223-240

Eppley, R. W. (1986). Plankton dynamics of the Southern California Bight. Springer-Verlag, New York

Eppley, R. W., Harrison, W. G., Chisholm, S. W., Stewart, E (1977). Particulate organic matter in surface waters off Southern California and its relationship to phytoplankton J. mar. Res. 35: 671-696

Eppley, R. W., Peterson, B. J. (1979). Particulate organic matter flux and planktonic new production in the deep ocean Nature, Lond. 282: 677-680

Eppley, R. E., Swift, E., Redalje, D. G., Landry, M. R., Haas, L. W. (1988). Subsurface chlorophyll maximum in August-September 1985 in the CLIMAX area of the North Pacific Mar Ecol. Prog. Ser. 42: 289-301

Fowler, S. W., Knauer, G. A. (1986). Role of large particles in the transport of elements and organic compounds through the oceanic water column. Prog. Oceanog. 16: 147-194

Fuhrman, J. A., Ammerman, J. W., Azam, F. (1980). Bacterioplankton in the coastal euphotic zone: distribution, activity and possible relationships with phytoplankton. Mar. Biol. 201-207

Fuhrman, J. A., Azam, F. (1982). Thymidine incorporation as a measure of heterotrophic bacterioplankton production in marine surface waters: evaluation and field results. Mar Biol. 66: 109-120

Fuhrman, J. A., Sleeter, T D., Carlson, C. A., Proctor, L. M. (1989). Dominance of bacterial biomass in the Sargasso Sea and its ecological implications. Mar. Ecol. Prog. Ser 57: $207-217$

Hobbie, J. E., Daley, R. J., Jasper, S. (1977). Use of Nuclepore filters for counting bacteria by fluorescence microscopy. Appl. environ. Microbiol. 33: 1225-1228

Laws, E. A., DiTullio, G. R., Redalje, D. G. (1987). High phytoplankton growth and production rates in the North Pacific subtropical gyre. Limnol. Oceanogr 32: 905-918

Lee, S.-H., Fuhrman, J. A. (1987). Relationships between biovolume and biomass of naturally derived marine bacterioplankton. Appl. environ. Microbiol. 53: 1298-1303

Linley, E. A. S., Newell, R. C., Lucas, M. I. (1983). Quantitative relationships between phytoplankton, bacteria and heterotrophic microflagellates in shelf waters. Mar Ecol. Prog. Ser. 12: 77-89

Maeda, M., Lee, W., Tàga, N. (1983). Distribution of lipopoly saccharide, an indicator of bacterial biomass, in subtropical areas of the sea. Mar Biol. 76: 257-262

Nagata, T (1986). Carbon and nitrogen content of natural planktonic bacteria. Appl. environ. Microbiol. 52: 28-32

Phinney, D. A., Yentsch, C. S. (1986). The relationship between phytoplankton and light attenuation in ocean waters. SPIE vol. 637 Ocean Optics VIII: 321-327

Porter, K. G., Feig, Y. S. (1980). The use of DAPI for identifying and counting aquatic microflora. Limnol. Oceanogr. 25: 943-948

Redalje, D. G. (1983). Phytoplankton carbon biomass and specific growth rates determined with the labeled chlorophyll a technique. Mar. Ecol. Prog. Ser 11:217-225

Redalje, D., Laws, E. (1981). A new method for estimating phytoplankton growth rates and carbon biomass. Mar. Biol. 62: 73-79

Sharp. J. H. (1974). Improved analysis for particulate organic carbon and nitrogen from seawater. Limnol. Oceanogr. 19: 984-989

Simon, M., Azam, F. (1989). Protein content and protein synthesis of planktonic marine bacteria. Mar. Ecol. Prog. Ser. 51. $201-213$ 
Smith, R. C., Baker, K. S. (1978). The bio-optical state of ocean waters and remote sensing. Limnol. Oceanogr. 23, 247--259 Spinrad, R. W., Glover, H., Ward, B. B., Codispoti, L. A., Kullenberg, G. (1989). Suspended particle and bacterial maxima in Peruvian coastal waters during a cold water anomaly. Deep Sea Res. 36: 715-733

This article was presented by Professor N. D. Holland,

La Jolla, California, USA
Strickland, J. D. H., Parsons, T R. (1972). A practical handbook of seawater analysis. Bull. Fish. Res. Bd Can. 167 $1-311$

Williams, P. M., Carlucci, A. F., Olson, R. (1980). A deep profile of some biologically important properties in the central North Pacific gyre. Oceanologica Acta 3: 471-476

Manuscript first received: October 15, 1989

Revised version accepted: February 19, 1990 